\title{
Pengaruh Variasi Dimensi Wadah dan Fermentasi terhadap Kualitas Biji Kakao (Theabroma cacao
} L.) Kering

\section{The Effect of Variation of Container Dimension and Long Fermentation of the Quality Cocoa (Theabroma cacao L.) Beans}

\author{
I Nyoman Arinata, Ni Luh Yulianti, Gede Arda \\ Program Studi Teknik Pertanian, Fakultas Teknologi Pertanian Universitas Udayana \\ E-mail: yulianti@unud.ac.id
}

\begin{abstract}
Abstrak
Tujuan dari penelitian ini adalah untuk mengetahui pengaruh variasi dimensi wadah dan lama fermentasi terhadap kualitas biji kakao kering dari hasil fermentasi dengan variasi dimensi wadah yang berbeda dan juga untuk mengetahui perlakuan terbaik dari hasil pengeringan biji kakao setelah proses fermentasi. Penelitian ini menggunakan rancangan acak lengkap faktorial dengan dua faktor, yaitu faktor pertama adalah variasi dimensi wadah yang berbeda-beda dan faktor kedua adalah lama fermentasi, yang terdiri dari tiga taraf yaitu 5 hari, 6 hari dan 7 hari. Hasil dari penelitian yang dilakukan menunjukkan bahwa perlakuan dimensi wadah dan lama fermentasi berpengaruh terhadap suhu fermentasi, jumlah biji per 100 gram, kadar air, kadar kulit dan hasil uji belah yaitu biji tidak terfermentasi, biji setengah terfermentasi dan biji terfermentasi sempurna. Dari hasil pengamatan yang telah dilakukan, perlakuan yang terbaik pada parameter suhu fermentasi adalah perlakuan dimensi wadah kotak kayu paling besar dengan lama fermentasi 6 hari, yang menunjukkan jumlah dari hasil uji belah biji terfermentasi sempurna paling banyak dibandingkan dengan uji belah tidak terfermentasi dan biji setengan terfermentasi.
\end{abstract}

Kata kunci: Dimensi wadah, waktu fermentasi, pengeringan biji kakao, suhu fermentasi

\begin{abstract}
The purpose of this study was to determine the effect of variations in container dimensions and fermentation time on the quality of dried cocoa beans from fermented with different container dimensions variations and also to determine the best treatment of the results of drying cocoa beans after the fermentation process. This research uses a factorial completely randomized design with two factors, namely the first factor is the variation of different container dimensions and the second factor is the fermentation time, which consists of three levels, namely 5 days, 6 days and 7 days. The results of the research carried out showed that the dimensions of the container treatment and fermentation time affect the fermentation temperature, the number of seeds per 100 grams, water content, skin content and the results of the split test ie unfermented seeds, semi-fermented seeds and perfectly fermented seeds. From the results of observations that have been made, the best treatment on the fermentation temperature parameters is the largest dimension of the wooden box container treatment with 6 days fermentation time, which shows the number of results of the most perfectly fermented seed splitting test is the most compared to the unfermented split test and fermented half seed.
\end{abstract}

Keyword: Container dimensions, fermentation time, cocoa beans drying, and fermentation temperature.

\section{PENDAHULUAN}

Kakao merupakan salah satu komoditas perkebunan yang memegang peranan cukup penting di Indonesia saat ini, salah satunya sebagai sumber divisa Negara. Produksi biji kakao di Indonesia pada periode Januari-Maret tahun 2018 jumlah produksi kakao mencapai 6.125 ton. Untuk periode Januari-Maret tahun 2019, Indonesia hanya mampu memproduksi kakao mencapai 3.729 ton, turun $61 \%$ dibandingkan pada tahun 2018. Kondisi ini diikuti oleh kualitas yang akan dihasilkan, dimana kualitas biji kakao kering yang dihasilkan masih tergolong rendah dan beragam, yaitu diantaranya biji tidak kering, ukuran biji tidak seragam, dan biji tidak terfermentasi.
Salah satu proses yang sangat berperan penting pada kualitas biji kakao yang dihasilkan adalah proses fermentasi dan proses pengeringan (Wahyudi dkk., 2008). Dalam proses fermentasi biji kakao, faktor yang dapat berpengaruh terhadap kualitas biji kakao adalah lama atau waktu fermentasi. Selain dari lama fermentasi dan jenis wadah fermentasi yang digunakan dalam proses fermentasi, faktor-faktor fermentasi yang dapat mempengaruhi kualitas biji kakao yang dihasilkan adalah varietas dan kondisi awal biji kakao yang difermentasi, dimensi wadah fermentasi, derajat aerasi wadah, tebal tumpukan biji dalam wadah fermentasi, dan lamanya proses fermentasi (Mulato et al, 2005; Indarti et al., 2011). Dari beberapa factor tersebut, kapasitas fermentasi yang mengacu kepada dimensi wadah fermentasi dan 
lama fermentasi menjadi faktor yang sangat penting untuk menghasilkan kakao dengan kualitas yang baik. Hasil penelitian yang telah dilakukan oleh Nursalam (2016) menunjukkan bahwa kualitas biji kakao lindak yang difermentasi selama 6 hari menghasilkan biji kakao kering yang paling baik dengan menggunakan kotak kayu. Penelitian yang dilakukan oleh Aryani, N., Yulianti, N., \& Arda, G (2018) diketahui bahwa fermentasi biji kakao dalam kapasitas 7,5 kg menggunakan kotak kayu memberikan respon yang lebih baik dibandingkan jenis wadah fermentasi lainnya terhadap mutu biji kakao kering hasil fermentasi, namun dalam penelitian tersebut, belum dilakukan kajian tentang kapasitas fermentasi lainnya dengan variasi dimensi wadah yang mampu memberikan hasil yang lebih baik terhadap mutu biji kakao kering hasil fermentasi.

Maka dari itu perlunya dilakukan penelitian mengenai pengaruh variasi dimensi wadah dan lama fermentasi terhadap kualitas biji kakao kering. Tujuan dilakukannya penelitian ini adalah untuk mengetahui pengaruh dari variasi dimensi wadah fermentasi, dan lama fermentasi terhadap kualitas biji kakao hasil fermentasi, dan untuk menentukan dimensi wadah fermentasi, dan lama fermentasi yang terbaik yang nantinya mampu menghasilkan biji kakao kering yang paling baik.

\section{METODE PENELITIAN}

\section{Parameter Pengamatan}

\section{Suhu Fermentasi Biji Kakao Basah}

Pengukuran suhu biji kakao basah akan dilakukan selama proses fermentasi berlangsung setiap 12 jam sekali. Pengukuran suhu ini menggunakan alat thermometer digital yang dilakukan dengan cara menancapkan ujung thermometer di tengah-tengah wadah setiap kali pengukuran suhu dilakukan.

\section{Kadar Air}

Pengukuran kadar air menggunakan metode oven (SNI, 2323:2008), yakni dimulai dengan cara mengeringkan cawan kosong terlebih dahulu selama 10 menit (M0) kemudian biji kakao kering dipecahkan dan ditimbang sebanyak 3 gram lalu dimasukkan ke dalam cawan tersebut. Cawan beserta isinya (M1) ditempatkan dalam oven pada suhu $\left(103^{\circ} \mathrm{C} \pm 2^{\circ} \mathrm{C}\right)$ dengan waktu 16 jam dengan tidak membuka oven sama sekali. Setelah 16 jam, cawan dengan isinya dimasukkan ke desikator. Kemudian timbang cawan beserta isinya tersebut (M2). Kadar air dinyatakan dalam persentase bobot seperti berikut

Kadar air $=\frac{(M 1-M 2)}{(M 1-M 0)} \times 100 \%$

Dimana Mo = bobot cawan dan tutupnya, dinyatakan dalam gram; $\mathbf{M}_{1}=$ bobot cawan, tutup dan contoh uji sebelum pengeringan, dinyatakan dalam gram; serta $\mathrm{M}_{2}=$ bobot cawan, tutup dan contoh uji sesudah pengeringan, dinyatakan dalam gram.

\section{Jumlah Biji per 100 gram}

Pengukuran jumlah biji per 100 gram dilakukan dengan cara menimbang biji kakao kering sebanyak 100 gram kemudian dihitung jumlah biji yang terdapat dalam 100 gram tersebut (BSN, 2008). Pengujian jumlah hasil dinyatakan sesuai dengan jumlah biji yang dihitung dalam 100 gram antara lain

AA: jumlah biji maksimum 85 biji per seratus gram; A: jumlah biji 86 - 100 biji per seratus gram;

B: jumlah biji 101 - 110 biji per seratus gram;

C: jumlah biji 111 - 120 biji per seratus gram;

S: jumlah biji lebih dari 120 biji per seratus.

\section{Kadar Kulit}

Pengukuran kadar kulit dilakukan dengan cara dipisahkan secara manual keping biji (nib) dan kulit kakao kemudian dilakukan penimbangan (SNI 2323:2008). Pengujian dilakukan dengan menggunakan biji kakao kering yang masih utuh kulitnya sebanyak $100 \pm 2$ gram (M0), kemudian dipisahkan nib dan kulit kakao tersebut. Setelah itu, dihitung bobot cawan yang masih kosong (M1). Ditimbang cawan yang sudah berisi kulit kakao (M2). Kadar kulit dinyatakan dalam persentase dengan rumus sebagai berikut:

$$
\text { Kadar kulit }=\frac{(M 2-M 1)}{M 0} \times 100 \%
$$

Dimana Mo = kulit biji kakao kering yang masih utuh; $\mathrm{M}_{1}=$ bobot cawan yang masih kosong; $\mathrm{M}_{2}=$ cawan yang sudah berisi kulit kakao.

\section{Uji Belah/ Cut Test}

Pengujian ini dilakukan dengan cara mengamati perubahan warna secara visual dan subyektif. Sebanyak 50 biji kakao dibelah membujur tepat dibagian tengahnya menjadi dua dengan ukuran yang sama besar. Dari 100 belahan biji tersebut diamati satu per satu warna keping biji kakao berdasarkan klasifikasinya. Pada penelitian ini dilakukan klasifikasi menjadi tiga kelas dominan terhadap cokelat ke dalam klas biji underfermented, dan cokelat dominan masuk klas biji fermented. Kemudian dihitung persentasenya dengan rumus sebagai berikut :

$$
\begin{aligned}
& \% \text { Biji Tidak terfermentasi }= \\
& \Sigma \frac{\text { belahan biji berwarna slaty }}{\text { belahan total bijikakao }} \quad x 100 \%
\end{aligned}
$$


$\%$ Biji Setengah terfermentasi

$\Sigma \frac{\text { belahan biji berwarna ungu }}{\text { belahan total biji kakao }} \quad x 100 \%$

$\%$ Biji Terfermentasi Sempurna

$\Sigma \frac{\text { belahan biji berwarna coklat }}{\text { belahan total biji kakao }} \quad x 100 \%$

Selain untuk mengukur persentase warna biji kakao kering, uji belah juga digunakan untuk mengukur kadar biji cacat meliputi berjamur, berkecambah dan berserangga. Pengujian dilakukan dengan membelah biji kakao kering sebanyak 50 biji kemudian dibelah secara membujur tepat di bagian tengahnya sehingga menjadi dua belahan dengan ukuran yang sama besar. Dari 100 belahan biji kakao kering tersebut kemudian diamati satu per satu, ada atau tidaknya biji berjamur, berkecambah dan berserangga. Persentasenya dihitung dengan menggunakan rumus sebagai berikut :

$$
\begin{aligned}
& \% \text { Biji Berjamur }= \\
& \sum \frac{\text { belahan biji berjamur }}{\text { belahan total biji kakao }} \quad x 100 \% \\
& \% \text { Biji Berkecambah }= \\
& \sum \frac{\text { belahan biji berkecambah }}{\text { belahan total biji kakao }} \quad x 100 \% \\
& \begin{array}{l}
\text { Biji Berserangga }= \\
\Sigma \frac{\text { belahan biji berserangga }}{\text { belahan total biji kakao }}
\end{array} \quad x 100 \%
\end{aligned}
$$

\section{Tempat dan Waktu Penelitian}

Penelitian ini dilakukan dengan 2 tahap, tahap pertama dilakukan proses fermentasi di Desa Medahan, Kecamatan Blahbatuh, Kabupaten Gianyar dan tahap kedua dilakukan di Laboratorium Teknik Pasca Panen, Laboraturium Pengolahan Pangan dan Laboratorium Analisis Pangan Fakultas Teknologi Pertanian Universitas Udayana. Penelitian ini dilakukan pada bulan Mei sampai Juni 2019.

\section{Bahan dan Alat Penelitian}

Bahan yang digunakan dalam penelitian ini antara lain, biji kakao jenis lindak/bulk cocoa yang diperoleh dari petani yang berada di Desa Gadungan, Kecamatan Selemadeg Timur dan diterima dalam bentuk buah kakao yang sudah disortasi dan dikumpulkan sehari sebelum fermentasi. Peralatan yang digunakan pada penelitian ini antara lain, timbangan manual skala $150 \mathrm{~kg}$ (Model Kresno, Indonesia), timbangan skala $5 \mathrm{~kg}$ (Model Camry), timbangan analitik (Model Shimadzu, Jepang), thermometer digital (Model TP3001), ember, loyang, rumpang, desikator, oven (Model Blue-m), pisau, talenan, kamera, spidol dan alat tulis.
$=$ Rancangan Percobaan

Penelitian ini menggunakan Rancangan Acak Lengkap (RAL) dengan 2 faktor. Faktor I (A) yaitu variasi dimensi wadah fermentasi (berdasarkan kapasitas berbeda) dengan 3 ukuran yang berbeda, dan faktor II (B) yaitu lama fermentasi yang terdiri dari 3 taraf.

Faktor I : Dimensi Wadah Fermentasi (A)

A1 = Dimensi wadah fermentasi berukuran $19,5 \mathrm{~cm} \mathrm{x}$ $19,5 \mathrm{~cm}$ x 25,5 cm dengan kapasitas $5,5 \mathrm{~kg}$

A2 = Dimensi wadah fermentasi berukuran $21,5 \mathrm{~cm} \mathrm{x}$ $21,5 \mathrm{~cm}$ x $28 \mathrm{~cm}$ dengan kapasitas $7,5 \mathrm{~kg}$

A3 = Dimensi wadah fermentasi berukuran $23,5 \mathrm{~cm} \mathrm{x}$ $23,5 \mathrm{~cm} \times 29,5 \mathrm{~cm}$ dengan kapasitas $9,5 \mathrm{~kg}$

Faktor II : Waktu Fermentasi (B)

$\mathrm{B} 1=5$ hari

$\mathrm{B} 2=6$ hari

$\mathrm{B} 3=7$ hari

Dari faktor variasi dimensi wadah dan lama fermentasi pada proses fermentasi akan diperoleh sebanyak sembilan kombinasi perlakuan yaitu :

A1B1 : Kotak kayu/ wadah fermentasi berukuran $19,5 \times 19,5 \times 25,5 \mathrm{~cm}$ (A1) dengan kombinasin perlakuan waktu fermentasi 5 hari (B1)

A1B2 : Kotak kayu/ wadah fermentasi berukuran $19,5 \times 19,5 \times 25,5 \mathrm{~cm}$ (A1) dengan kombinasin perlakuan waktu fermentasi 6 hari (B2)

A1B3 : Kotak kayu/ wadah fermentasi berukuran $19,5 \times 19,5 \times 25,5 \mathrm{~cm}$ (A1) dengan kombinasin perlakuan waktu fermentasi 7 hari (B3)

A2B1 : Kotak kayu/ wadah fermentasi berukuran $21,5 \times 21,5 \times 28 \mathrm{~cm}$ (A2) dengan kombinasin perlakuan waktu fermentasi 5 hari (B1)

A2B2 : Kotak kayu/ wadah fermentasi berukuran $21,5 \times 21,5 \times 28 \mathrm{~cm}$ (A2) dengan kombinasin perlakuan waktu fermentasi 6 hari (B2)

A2B3 : Kotak kayu/ wadah fermentasi berukuran $21,5 \times 21,5 \times 28 \mathrm{~cm}$ (A2) dengan kombinasin perlakuan waktu fermentasi 7 hari (B3)

A3B1 : Kotak kayu/ wadah fermentasi berukuran $23,5 \times 23,5 \times 29,5 \mathrm{~cm}$ (A3) dengan kombinasin perlakuan waktu fermentasi 5 hari (B1)

A3B2 : Kotak kayu/ wadah fermentasi berukuran $23,5 \times 23,5 \times 29,5 \mathrm{~cm}$ (A3) dengan kombinasin perlakuan waktu fermentasi 6 hari (B2)

A3B3 : Kotak kayu/ wadah fermentasi berukuran $23,5 \times 23,5 \times 29,5 \mathrm{~cm}$ (A3) dengan kombinasin perlakuan waktu fermentasi 7 hari (B3)

Seluruh perlakuan diulang sebanyak 3 kali ulangan sehingga didapatkan 27 data pengamatan. Data yang 
diperoleh dianalisis dengan sidik ragam dan apabila terdapat pengaruh perlakuan yang signifikan (P>0.05) maka dilanjutkan dengan uji BNT terhadap rata-rata perlakuan. Perlakuan terbaik dipilih dari perlakuan yang menghasilkan nilai paling mendekati standar SNI 2323:2008.

\section{Pelaksanaan Penelitian}

Buah kakao (Theabroma cacao L.) yang diperoleh dari Desa Gadungan, Kecamatan Selemadeg Timur, Tabanan. Selanjutnya untuk mendapatkan bagian biji kakao dari buahnya, dilakukan pemecahan buah kakao untuk mengeluarkan dan memisahkan biji kakao dari kulit buah dan placentanya. Biji kakao yang dipergunakan pada saat fermentasi yaitu biji kakao yang sudah terpisah dari kulitnya. Bahan baku biji kakao yang digunakan untuk masing-masing perlakuan adalah sebanyak 5,5 kg, 7,5 dan 9,5 kg biji kakao.

\section{Tahap Fermentasi}

Proses fermentasi yang dilakukan dalam penelitian ini adalah menggunakan teknologi dengan variasi dimensi wadah dan lama fermentasi untuk mendapatkan kualitas biji kakao yang terbaik. Cara fermentasi adalah dengan membelah buah kakao untuk mendapatkan biji kakao segar, selanjutnya biji kakao ditumpuk dalam kotak kayu, kemudian ditutup dengan daun pisang dan karung goni. Selama fermentasi, biji kakao dihindarkan bersinggungan dengan logam. Biji kakao dibalikkan setelah 72 jam (hari ke 3) proses fermentasi. Proses fermentasi dihentikan pada saat waktu yang sudah ditentukan. Setelah fermentasi selesai dengan waktu yang sudah ditentukan, biji dikeluarkan lalu dilakukan perendaman selama 2 sampai 3 jam dan dicuci bersih, untuk siap dikeringkan menggunakan oven hingga kadar air mencapai $6-7,5 \% \mathrm{Bb}$.

\section{HASIL DAN PEMBAHASAN}

\section{Suhu Fermentasi Biji Kakao Basah}

Proses fermentasi terjadi secara alami yang disebabkan oleh mikroba dengan bantuan oksigen dari lingkungan luar masuk ke dalam wadah fermentasi melalui lubang-lubang aerasi. Fermentasi dapat berjalan dengan baik jika adanya cukup oksigen dan akan menghasilkan panas (perubahan suhu) yang merupakan hasil oksidasi senyawa gula di dalam pulpa (lendir) (Rohan, 1963). Proses fermentasi dapat diketahui melalui perubahan suhu fermentasi mulai dari aktivitas proses fermentasi awal hingga akhir proses fermentasi. Perubahan suhu selama proses fermentasi dipengaruhi oleh beberapa faktor yaitu pada saat pembalikan (pengadukan), aerasi dan berat biji basah. Berikut adalah tabel perubahan suhu fermentasi biji kakao dapat dilihat pada Tabel 1.

Tabel 1. Nilai rata-rata suhu biji kakao basah selama fermentasi

\begin{tabular}{llllllllll}
\hline Waktu (jam) & \multicolumn{8}{c}{ Suhu pada perlakuan $\left({ }^{\circ} \mathbf{C}\right)$} \\
& $\mathbf{A 1 B 1}$ & $\mathbf{A 1 B 2}$ & $\mathbf{A 1 B 3}$ & $\mathbf{A 2 B 1}$ & $\mathbf{A 2 B 2}$ & $\mathbf{A 2 B 3}$ & $\mathbf{A 3 B 1}$ & $\mathbf{A 3 B 2}$ & $\mathbf{A 3 B 3}$ \\
\hline 0 & 29,10 & 29,30 & 29,20 & 29,35 & 29,40 & 29,45 & 29,50 & 29,60 & 29,55 \\
12 & 37,30 & 38,30 & 32,80 & 38,90 & 37,50 & 37,20 & 38,60 & 38,20 & 36,80 \\
24 & 38,70 & 39,30 & 35,20 & 39,60 & 39,50 & 39,20 & 39,40 & 39,50 & 38,40 \\
36 & 42,20 & 41,20 & 38,20 & 41,70 & 42,00 & 40,00 & 40,50 & 42,50 & 39,90 \\
48 & 41,00 & 40,70 & 37,50 & 42,30 & 43,80 & 41,00 & 42,90 & 44,90 & 40,60 \\
60 & 42,50 & 42,20 & 40,30 & 42,90 & 45,20 & 41,90 & 43,50 & 45,50 & 42,10 \\
72 & 43,90 & 43,30 & 41,40 & 44,40 & 43,60 & 42,70 & 44,00 & 43,20 & 44,10 \\
84 & 44,70 & 41,20 & 40,50 & 44,90 & 43,60 & 44,90 & 45,10 & 43,90 & 45,40 \\
96 & 37,80 & 38,30 & 38,20 & 38,40 & 37,60 & 37,60 & 37,80 & 38,10 & 37,60 \\
108 & 35,70 & 36,30 & 36,80 & 35,90 & 36,00 & 36,10 & 35,70 & 36,50 & 36,40 \\
120 & 33,50 & 34,00 & 38,00 & 34,20 & 34,10 & 35,40 & 33,60 & 34,90 & 35,70 \\
132 & & 32,70 & 34,10 & & 32,20 & 34,00 & & 32,90 & 35,40 \\
144 & & 31,20 & 32,60 & & 31,00 & 32,50 & & 31,30 & 34,00 \\
156 & & & 31,10 & & & 31,90 & & & 32,50 \\
168 & & & 30,40 & & & 30,30 & & & 31,30 \\
\hline
\end{tabular}

Keterangan: Angka yang diwarnai merah menunjukkan pencapaian suhu optimal/ suhu tertinggi yang terjadi setelah 48 jam fermentasi.

Berdasarkan data yang disajikan pada Tabel 1 terlihat bahwa suhu awal fermentasi mula-mula berkisar antara $29,10^{\circ} \mathrm{C}-29,60{ }^{\circ} \mathrm{C}$ untuk semua perlakuan. Selanjutnya, untuk semua perlakuan mengalami peningkatan suhu dari awal proses fermentasi hingga jam ke-36. Berdasarkan Tabel
1, diketahui bahwa peningkatan suhu terjadi pada perlakuan A2B1, A2B2, A2B3 dengan nilai berturut-turut sebesar $42,30^{\circ} \mathrm{C}, 43,80^{\circ} \mathrm{C}, 41,00^{\circ} \mathrm{C}$ pada jam ke-48, peningkatan suhu tersebut lebih lambat dibandingkan dengan peningkatan suhu pada perlakuan A3B1, A3B2, A3B3 dengan suhu 
sebesar $42,90^{\circ} \mathrm{C}, 44,90{ }^{\circ} \mathrm{C}, 40,60^{\circ} \mathrm{C}$ pada jam ke48. Hal ini disebabkan oleh adanya pengurangan lendir dari biji kakao sebelum proses fermentasi paling banyak terjadi pada dimensi wadah fermentasi berukuran $23,5 \mathrm{~cm}$ x 23,5 $\mathrm{cm}$ x 29,5 cm (A3). Selanjutnya perlakuan A1B1, A2B1, A2B2, A3B1, dan A3B3 dapat mencapai suhu optimal yaitu berkisar $44-48{ }^{\circ} \mathrm{C}$, tetapi pencapaian suhunya lambat. Hal ini disebabkan oleh lapisan dari lendir pada biji kakao (pulp) yang masih banyak menempel pada biji dan masih terlalu tebal yang dapat memperlambat penetrasi oksigen yang masuk ke dalam tumpukan biji kakao fermentasi (Mahardika, 2015).

Hal lain yang menyebabkan suhu lambat pada proses fermentasi yaitu aktivitas mikroba dalam pulp yang berbeda-beda dalam setiap dimensi wadah fermentasi. Hal ini terlihat bahwa variasi dimensi wadah fermentasi dapat mempengaruhi perubahan suhu fermentasi biji kakao. Gumbira (1978) dalam Atiqoh (2007) menyatakan peningkatan suhu fermentasi disebabkan oleh perubahan gula menjadi alkohol. Menurut Haryadi dan Supriyanto (1991), aktivitas khamir merubah gula menjadi alkohol merupakan reaksi yang bersifat isotermis, karena selama fermentasi akan menghasilkan panas dan menyebabkan suhu massa kakao yang difermentasi menjadi lebih tinggi. Terlihat pada Tabel 1 di atas, suhu fermentasi mengalami fluktuasi yang tidak konstan pada perlakuan A1B1, A1B2, A1B3 yang disebabkan oleh aktivitas mikroba dalam pulp yang masih terlalu tebal, sehingga dapat memperlambat penetrasi oksigen masuk ke dalam tumpukan biji kakao yang difermentasi yang membuat suhu fermentasi kurang stabil.

Dari semua kombinasi perlakuan, perlakuan yang mampu mencapai suhu optimal setelah jam ke-48 adalah interaksi perlakuan A3B2 yaitu sebesar $44,90{ }^{\circ} \mathrm{C}$. Untuk perlakuan lain yang mampu mencapai suhu paling tinggi adalah perlakuan A2B2 sebesar $45,20^{\circ} \mathrm{C}$ pada jam ke-60; A3B1 sebesar $45,10^{\circ} \mathrm{C}$ pada jam ke-84; A3B2 sebesar $45,50^{\circ} \mathrm{C}$ pada jam ke-60; A3B3 sebesar $45,40^{\circ} \mathrm{C}$ pada jam ke-84. Menurut Amin (2005), suhu fermentasi yang dibutuhkan untuk fermentasi kakao segar agar memperoleh hasil yang terbaik adalah pada suhu $44-48{ }^{\circ} \mathrm{C}$, yaitu terjadi setelah 48 jam fermentasi. Pada saat proses fermentasi awal biasanya dipengaruhi oleh yeast (khamir), kemudian digantikan oleh pertumbuhan bakteri asam laktat. Selanjutnya pulp akan mulai mencair dan oksigen akan mulai masuk ke dalam wadah fermentasi yang dapat menyebabkan bakteri asam asetat yang mempengaruhi proses fermentasi dan menghasilkan asam asetat seingga hal ini dapat mengakibatkan peningkatan suhu fermentasi mencapai $50^{\circ} \mathrm{C}$. Setelah suhu fermentasi mencapai suhu optimal, selanjutnya suhu akan mengalami penurunan hingga proses fermentasi terhenti. Menurut Kustyawati dan Setyani (2008), fermentasi menentukan kualitas produk akhir karena adanya reaksi eksothermal yang dapat menyebabkan terjadinya difusi zat-zat metabolit ke dalam biji kakao, sehingga dapat menyebabkan biji mati, kemudian terjadi rekasi enzimatis pembentukan aroma, flavor dan warna.

\section{Kadar Air}

Kadar air merupakan faktor yang sangat penting untuk penentuan kualitas biji kakao kering yang dihasilkan. Kadar air juga merupakan banyaknya air yang tergantung di dalam suatu bahan yang dapat dinyatakan dalam persen (\%). Selain berpengaruh terhadap rendemen hasil, kadar air berpengaruh pada daya tahan biji kakao terhadap kerusakan, terutama saat penggudangan dan pengangkutan. Biji kakao yang mempunyai kadar air tinggi, sangat sensitif terhadap serangan jamur dan serangga. Kadar air biji kakao juga ditentukan dengan cara pengeringan dan penyimpanannya serta merupakan salah satu karakteristik yang sangat penting pada bahan karena dapat mempengaruhi penampakan, tekstur dan cita rasa pada bahan pangan (Winarno, 1993).

Hasil dari analisis sidik ragam menunjukkan bahwa perlakuan dimensi wadah fermentasi dan interkasi antar perlakuan berpengaruh sangat nyata $(\mathrm{P}<0,01)$ terhadap kadar air biji kakao, selanjutnya perlakuan lama fermentasi tidak berpengaruh nyata $(P>0,05)$ terhadap kadar air biji kakao. Untuk nilai rata-rata kadar air dan hasil uji BNT dapat dilihat pada Tabel 2.

Berdasarkan data yang disajikan pada Tabel 2, diketahui bahwa nilai rata-rata kadar air yang memenuhi standar SNI 2323:2008 adalah perlakuan A3B2 yaitu biji kakao yang difermentasi dalam kotak kayu berukuran $23,5 \mathrm{~cm}$ x 23,5 cm x 29,5 cm dengan kapasitas $9,5 \mathrm{~kg}$ selama 6 hari yaitu sebesar $74 \%$ bb. Selanjutnya berdasarkan hasil uji lanjut yang dilakukan, diketahui bahwa perlakuan A3B2 memberikan pengaruh yang tidak berbeda nyata dengan perlakuan A3B3 tetapi memberikan pengaruh yang berbeda nyata dibandingkan perlakuan lainnya. 
Tabel 2. Nilai rata-rata kadar air $(\%$ bb)

\begin{tabular}{ccccc} 
Dimensi Wadah & \multicolumn{3}{c}{ Lama Fermentasi } & Rata-rata \\
& B1 & $\mathbf{B 2}$ & $\mathbf{B 3}$ & \\
A1 & $9,8 \mathrm{e}$ & $9,1 \mathrm{c}$ & $9,1 \mathrm{c}$ & 9,3 \\
A2 & $8,8 \mathrm{c}$ & $9,4 \mathrm{~d}$ & $8,8 \mathrm{c}$ & 9,0 \\
A3 & $8,0 \mathrm{~b}$ & $7,4 \mathrm{a}$ & $7,8 \mathrm{a}$ & 7,8 \\
\cline { 1 - 4 } Rata-rata & 8,9 & 8,6 & 8,6 & \\
\hline
\end{tabular}

Keterangan: Huruf yang sama dibelakang nilai rata-rata menunjukkan nilai yang tidak berbeda nyata $(\mathrm{P}>0,05)$.

Berdasarkan Tabel 2, terlihat bahwa perlakuan A3B2 sudah sesuai dengan standar SNI 2323:2008 yang nilai kadar air biji kakao menunjukkan nilai tidak melebihi $7,5 \% \mathrm{Bb}$. Tetapi kadar air yang terlalu rendah yaitu sebesar $5 \%$ juga tidak baik untuk kualitas biji kakao kering yang dihasilkan, karena akan menyebabkan biji kakao mudah rapuh atau pecah. Selanjutnya berdasarkan uji lanjut yang dilakukan, diketahui bahwa fermentasi selama 5 hari dan 7 hari belum bisa mencapai kadar air yang diinginkan sesuai standar SNI 2323:2008. Hal ini diduga masih adanya aktivitas mikroba dalam pulp yang berbeda-beda dalam setiap dimensi wadah fermentasi, sehingga menyebabkan aktivitas mikroba dalam pulp masih bekerja dan dapat menghambat kemampuan bahan unutuk melepaskan air dari permukaan bahan. Menurut penelitian Mulato dan Widyotomo (2003), menyatakan bahwa waktu fermentasi juga menjadi factor penting penyebab meningkatnya kadar air, sehingga dengan meningkatnya waktu fermentasi, kadar air dalam biji kakao juga akan meningkat,begitu sebaliknya ketika waktu fermentasi tidak mengalami peningkatan, maka kadar air pada biji kakao tidak meningkat.

Marwati (2013) menyatakan bahwa selama proses fermentasi akan terjadi kematian pada biji kakao yang akan menyebabkan sifat semipermeabilitas dari dinding sel menjadi rusak, sehingga dapat mempermudah air keluar dari selama pengeringan. Pada saat proses pengeringan, suhu yang terlalu tinggi juga dapat menyebabkan pengeringan yang tidak merata yang ditandai dengan biji bagian luar kering dan bagian dalam pada biji masih banyak mengandung air.

\section{Jumlah biji per 100 gram}

Jumlah biji per 100 gram merupakan komponen penting dalam penentuan mutu biji kakao yang dikeringkan, dimana semakin sedikit jumlah biji yang dihasilkan dalam jumlah biji per 100 gram, maka kualitas biji kakao kering yang dihasilkan semakin baik. Jumlah biji per 100 gram berkaitan dengan kadar air yang terkandung dalam biji. Semakin banyak jumlah biji per 100 gram biji, maka semakin kecil kandungan kadar air dalam biji kakao, sedangkan semakin tinggi nilai kadar air dalam biji maka jumlah biji per 100 gram akan lebih sedikit.

Hasil dari analisis sidik ragam menunjukkan bahwa perlakuan dimensi wadah fermentasi, perlakuan lama fermentasi dan interaksi antar perlakuan memberikan pengaruh sangat nyata $(\mathrm{P}<0,01)$ terhadap jumlah biji per 100 gram. Untuk nilai rata-rata jumlah biji per 100 gram dan hasil uji BNT dapat dilihat pada Tabel 3.

Tabel 3. Nilai rata-rata jumlah biji per 100 gram

\begin{tabular}{ccccc} 
Dimensi Wadah & \multicolumn{3}{c}{ Lama Fermentasi } & Rata-rata \\
& B1 & B2 & B3 & \\
A1 & $96 \mathrm{~d}$ & $91 \mathrm{c}$ & $89 \mathrm{~b}$ & 92 \\
A2 & $90 \mathrm{~b}$ & $89 \mathrm{~b}$ & $88 \mathrm{~b}$ & 89 \\
A3 & $91 \mathrm{c}$ & $83 \mathrm{a}$ & $83 \mathrm{a}$ & 86 \\
Rata-rata & 92 & 88 & 87 & \\
\cline { 1 - 3 }
\end{tabular}

Keterangan: Huruf yang sama dibelakang nilai rata-rata menunjukkan nilai yang tidak berbeda nyata $(\mathrm{P}>0,05)$.

Berdasarkan data yang disajikan pada Tabel 3, diketahui bahwa nilai rata-rata jumlah biji yang paling sedikit jumlahnya dalam 100 gram diperoleh pada perlakuan A3B2 yaitu dimensi wadah kotak kayu berukuran $23,5 \mathrm{~cm}$ x $23,5 \mathrm{~cm}$ x $29,5 \mathrm{~cm}$ dengan kapasitas $9,5 \mathrm{~kg}$ selama 6 hari dengan jumlah biji yang diperoleh sebanyak 83 biji. Selanjutnya perlakuan ini memberikan 
pengaruh yang tidak berbeda nyata dengan perlakuan A3B3 tetapi memberikan pengaruh yang berbeda nyata dibandingkan perlakuan lainnya. Hal ini menjadi kondisi yang paling baik, karena aktivitas mikroba dalam pulp sudah terlepas dan tidak menempel pada permukaan biji serta tidak menghambat penetrasi oksigen masuk ke dalam tumpukan biji kakao fermentasi (Mahardika, 2015) dan aktivitas mikroba akan menghasilkan asam, alkohol dan melepaskan panas (reaksi eksothermal) keluar dari wadah fermentasi.

Menurut Haryadi dan (Supriyanto, 1991), aktivitas khamir merubah gula menjadi alkohol merupakan reaksi yang bersifat isotermis, karena selama fermentasi akan menghasilkan panas dan menyebabkan suhu massa kakao yang difermentasi menjadi lebih optimal, hal ini dapat tercapai saat proses fermentasi selama 6 hari. Menurut hasil penelitian oleh (Nursalam, 2005) menunjukkan bahwa proses fermentasi selama 6 hari, memperlihatkan bahwa perlakuan paling baik diantara semua perlakuan. Sedikitnya jumlah biji kakao yang dihasilkan pada parameter ini yang menunjukkan kondisi paling baik dalam jumlah biji per 100 gram disebabkan oleh kandungan kadar air pada biji kakao tinggi. Hal ini dapat dilihat pada perlakuan A3B2 yang menunjukkan jumlah biji per 100 gram paling sedikit yaitu 83 biji, dibandingkan dengan perlakuan A1B1 yang mengahsilkan jumlah biji per 100 gram paling besar yaitu sebesar 96 biji. Namun dari data di atas menunjukkan bahwa perlakuan yang terbaik terlihat pada lama fermentasi 6 hari dan 7 hari, hal ini disebabkan oleh semakin lama fermentasi, semakin banyak juga kehilangan bobot biji karena berkurangnya cairan daging buah, peruraian sebagian kandungan keping biji dan penguapan air.

Berdasarkan syarat mutu biji kakao dapat digolongkan ke dalam lima kelas berdasarkan jumlah biji per 100 gram menurut SNI 2323:2008/ Amd 1: 2010 yaitu dapat dilihat pada Tabel 2, diketahui bahwa nilai rata-ata jumlah biji per 100 gram pada perlakuan A3B2 dan A3B3 dikategorikan ke dalam golangan kelas mutu AA karena nilai rata-rata jumlah biji kakao kering per 100 gram kurang dari 85 biji per 100 gram. Untuk perlakuan B1 yaitu lama fermentasi 5 hari dan perlakuan yang lain dikategorikan ke dalam golongan kelas mutu A karena nilai rata-rata jumlah biji kakao kering per 100 gram berkisar antara $86-100$ biji per 100 gram.

\section{Kadar Kulit}

Kulit biji kakao merupakan kulit tipis, lunak dan agak berlendir yang menyelubungi keping biji kakao. Persentasenya berkisar $10-16 \%$ dari keseluruhan bagian biji kakao kering (Fowler, 2009). Biji kakao terdiri dari keping biji (nib) yang dilindungi oleh kulit (shell). Kadar kulit dinding atas dasar perbandingan berat kulit dan berat total biji kakao (keping dan kulit) pada kadar air 6-7\%. Biji kakao dengan kadar kulit yang tinggi cenderung lebih kuat atau tidak rapuh saat ditumpuk di dalam gudang sehingga biji tersebut dapat disimpan dalam waktu yang lebih lama. Kadar kulit biji kakao dipengaruhi oleh cara pengolahan (fermentasi dan pencucian). Makin singkat waktu fermentasi, kadar kulit biji kakao akan semakin tinggi karena sebagian besar sisa lendir (pulp) masih menempel pada biji.

Hasil dari analisis sidik ragam menunjukkan bahwa interaksi antar perlakuan berpengaruh sangat nyata $(\mathrm{P}<0,01)$ terhadap kadar kulit biji kakao, selanjutnya perlakuan dimensi wadah dan lama fermentasi berpengaruh sangat nyata $(\mathrm{P}<0,01)$ terhadap kadar kulit biji kakao. Untuk nilai rata-rata kadar kulit biji kakao dan hasil uji BNT dapat dilihat pada Tabel 4.

Tabel 4. Nilai rata-rata kadar kulit (\%)

\begin{tabular}{ccccc} 
Dimensi Wadah & \multicolumn{3}{c}{ Lama Fermentasi } & Rata-rata \\
\cline { 1 - 3 } A1 & $\mathbf{B 1}$ & $\mathbf{B 2}$ & $\mathbf{B 3}$ & \\
$\mathrm{A} 2$ & $13,6 \mathrm{~d}$ & $13,07 \mathrm{c}$ & $13,26 \mathrm{c}$ & 13,33 \\
$\mathrm{~A} 3$ & $12,21 \mathrm{~b}$ & $13,23 \mathrm{c}$ & $13,39 \mathrm{c}$ & 12,94 \\
Rata-rata & $13,15 \mathrm{c}$ & $10,97 \mathrm{a}$ & $13,05 \mathrm{c}$ & 12,93 \\
\cline { 1 - 3 } & 13,00 & 12,42 & 13,23 & \\
\hline
\end{tabular}

Keterangan: Huruf yang sama dibelakang nilai rata-rata menunjukkan nilai yang tidak berbeda nyata $(\mathrm{P}>0,05)$.

Berdasarkan data yang disajikan pada Tabel 4, diketahui bahwa nilai rata-rata kadar kulit yang mendekati standar kadar kulit biji kakao terlihat pada perlakuan dimensi wadah kotak kayu berukuran $23,5 \mathrm{~cm} \times 23,5 \mathrm{~cm} \times 29,5$ dengan kapasitas 9,5 kg selama 6 hari (A3B2) yaitu 
sebesar $10,97 \%$ yang memberikan pengaruh yang berbeda nyata dibandingkan dengan perlakuan lainnya. Perlakuan ini memenuhi standar SNI 2323:2008 kadar kulit yang cukup baik karena nilai rata-rata yang didapat tidak melebihi $11 \%$. Selanjutnya berdasarkan hasil uji lanjut yang dilakukan, diketahui bahwa perlakuan dimensi wadah fermentasi yang memberikan nilai kadar kulit terbaik adalah perlakuan A3 yaitu dimensi kotak kayu berukuran paling besar dibandingkan dengan dimensi kotak kayu yang lainnya. Hal ini menunjukkan bahwa permukaan pada kulit biji kakao fermentasi sudah tidak adanya pulp yang masih menempel sehingga proses fermentasi mengalami tingkat keberhasilan sempurna yang dapat mengakibatkan kadar kulit biji mencapai standar yang diinginkan.

Menurut pernyataan (Rasadi, 2015), kadar kulit terendah yaitu berkisar $11 \%$ bb, karena semakin tinggi kadar kulit biji maka semakin rendah rendemen yang dapat dikonsumsi, sehingga berdampak pada rendahnya harga biji kakao kering yang dipasarkan. Diketahui bahwa, persen kadar kulit biji kakao tidak hanya dipengaruhi oleh tebal tipisnya kulit biji kakao, tapi juga dapat dipengaruhi oleh sisa pulp yang melekat pada kulit biji atau kotoran lain. Selain itu, proses fermentasi komponen pada keping biji yang berupa cairan keluar akibat eksudasi (proses yang menyebabkan keluarnya cairan yang mengandung sejumlah komponen terlarut dari suatu bahan) dan sebagian menempel pada kulit, sehingga meningkatnya kadar kulit biji. Kadar kulit yang tinggi disebabkan oleh adanya pulp yang masih menempel pada kulit ari (Wahyudi dkk.,2006). Semakin lama proses fermentasi berlangsung, proses penguraian karbohidrat akan semakin sempurna dan sisa pulp yang menempel pada kulit akan semakin sedikit sehingga kadar kulit biji kakao akan semakin rendah.

\section{Uji Belah/Cut Test \\ Biji Tidak Terfermentasi}

Biji tidak terfermentasi merupakan biji slaty yang memperlihatkan separuh atau lebih permukaan irisan keping biji berwarna keabu-abuan menyerupai sabak atau biru keabu-abuan yang memiliki tekstur padat dan pejal seperti keju (SNI 2323-2008 dalam BSN, 2008). Biji slaty akan memberikan rasa astringent (sepat) dan bitter (rasa pahit) yang berlebihan dan aroma biji kakao yang sangat rendah (Misnawi, 2008). Untuk standar SNI kadar kulit biji slaty (tidak terfermentasi) adalah sebesar maksimal $3 \%$ untuk kualitas mutu I.

Hasil dari analisis sidik ragam menunjukkan bahwa interaksi antar perlakuan, perlakuan dimensi wadah dan perlakuan lama fermentasi berpengaruh sangat nyata $(\mathrm{P}<0,01)$ terhadap hasil uji belah/cut test biji tidak terfermentasi. Nilai rata-rata hasil uji belah/cut test biji tidak terfermentasi dan hasil Uji BNT dapat dilihat pada Tabel 5 .

Tabel 5. Nilai rata-rata hasil uji belah biji tidak terfermentasi (\%)

\begin{tabular}{ccccc} 
Dimensi Wadah & \multicolumn{3}{c}{ Lama Fermentasi } & Rata-rata \\
& B1 & B2 & B3 & \\
A1 & $4 \mathrm{c}$ & $3 \mathrm{a}$ & $5 \mathrm{~d}$ & 4 \\
A2 & $3 \mathrm{a}$ & $3 \mathrm{~b}$ & $3 \mathrm{a}$ & 3 \\
A3 & $3 \mathrm{a}$ & $2 \mathrm{a}$ & $4 \mathrm{c}$ & 3 \\
\cline { 1 - 4 } Rata-rata & 3 & 3 & 4 & \\
\hline
\end{tabular}

Keterangan: Huruf yang sama dibelakang nilai rata-rata menunjukkan nilai yang tidak berbeda nyata $(\mathrm{P}>0,05)$.

Dari data yang disajikan pada Tabel 5, nilai ratarata kadar biji tidak terfermentasi yang terendah terdapat pada kombinasi perlakuan A1B2 sebesar 3\%, A2B1 3\%, A2B2 3\%, A2B3 3\%, A3B1 3\%, dan A3B2 2\%. Dari kombinasi perlakuan tersebut sudah memenuhi standar SNI 2323-2008 yaitu kadar kulit biji slaty (tidak terfermentasi) sebesar maksimal 3\% untuk kualitas mutu I. Oleh karena itu, kombinasi perlakuan tersebut telah memenuhi standar untuk kualitas mutu I biji kakao kering terfermentasi. Selanjutnya berdasarkan uji lanjut yang dilakukan perlakuan A1B2, A2B1, A2B2, A2B3, A3B1 dan A3B2 memberikan pengaruh yang berbeda nyata terhadap perlakuan lainnya. Mutu biji kakao kering dapat ditentukan secara fisik, kimia dan organoleptik. Secara fisik, tingkat kesempurnaan fermentasi dapat dilihat dari hasil uji belah (cut test). Dengan dilakukannya uji belah dapat dilihat warna dominan keping biji yang tidak terfermentasi berwarna ungu (violet) atau 
sering disebut dengan biji slaty. Berdasarkan Tabel 5, hasil dari nilai rata-rata biji tidak terfermentasi yang terbaik menunjukkan pada perlakuan A3B2. Hal ini dikarenakan persentase dari biji tidak terfermentasi pada perlakuan tersebut sebesar 2\%, yaitu tidak melebihi $3 \%$. Menurut (Misnawi et al., 2002), senyawa polifenol adalah penentu warna keping biji dan keberadaan polifenol tidak hanya bertanggung jawab terhadap pembentukan rasa pahit dan sepat, tetapi juga menyebabkan karaktersitik warna coklat pada biji kakao terfermentasi. Untuk biji tidak terfermentasi (slaty), ditandai dengan keping biji berwarna keabu-abuan, bertekstur pejal, memiliki rasa sangat pahit dan bercita rasa coklat.

\section{Biji Setengah Terfermentasi}

Biji setengah fermentasi merupakan biji yang proses fermentasinya belum cukup waktunya, yang menunjukkan warna coklat muda atau pucat dan ungu tua yang tidak merata, sebagian besar bentuknya gepeng, bila dibelah di dalamnya berwarna kelabu dan pejal serta warna biji coklat tua yang tidak ada pori-porinya.

Hasil dari analisis sidik ragam menunjukkan bahwa interaksi antar perlakuan tidak memberikan pengaruh nyata $(\mathrm{P}>0,05)$ terhadap hasil uji belah biji setengah terfermentasi, selanjutnya perlakuan dimensi wadah fermentasi berpengaruh nyata $(\mathrm{P}<0,05)$ terhadap biji setengah fermentasi, sedangkan perlakuan lama fermentasi memberikan pengaruh sangat nyata $(\mathrm{P}<0,01)$ terhadap hasil uji belah biji setengah terfermentasi. Nilai rata-rata hasil uji belah/cut test biji setengah terfermentasi dan hasil Uji BNT dapat dilihat pada Tabel 6 .

Tabel 6. Nilai rata-rata hasil uji belah biji setengah terfermentasi (\%)

\begin{tabular}{ccccc} 
Dimensi Wadah & \multicolumn{3}{c}{ Lama Fermentasi } & Rata-rata \\
& B1 & B2 & B3 & \\
A1 & $22 \mathrm{~b}$ & $23 \mathrm{c}$ & $25 \mathrm{~d}$ & 23 \\
A2 & $21 \mathrm{~b}$ & $21 \mathrm{a}$ & $27 \mathrm{f}$ & 23 \\
A3 & $20 \mathrm{a}$ & $18 \mathrm{a}$ & $25 \mathrm{e}$ & 21 \\
\cline { 1 - 4 } Rata-rata & 21 & 21 & 26 & \\
\hline
\end{tabular}

Keterangan: Huruf yang sama dibelakang nilai rata-rata menunjukkan nilai yang tidak berbeda nyata $(\mathrm{P}>0,05)$.

Berdasarkan data yang disajikan pada Tabel 6, diketahui nilai rata-rata dari hasil uji belah biji setengah terfermentasi terbanyak terdapat pada perlakuan A2B3 sebesar 27\%, yaitu perlakuan fermentasi selama 7 hari, yang memberikan pengaruh yang berbeda nyata dibandingkan perlakuan lainnya. Selanjutnya berdasarkan hasil uji lanjut, terlihat bahwa biji setengah fermentasi paling sedikit terdapat pada perlakuan A3B2 yaitu sebesar $18 \%$. Memberikan pengaruh yang tidak berbeda nyata dengan perlakuan A2B2 dan A3B1 tetapai memberikan pengaruh yang berbeda nyata dibandingkan perlakuan lainnya. Dilihat dari Tabel 6, menunjukkan bahwa nilai rata-rata dari biji setengah fermentasi lebih sedikit dari hasil uji belah biji terfermentasi sempurna yang hasil uji belahnya sudah dilakukan dengan jumlah belahan 100 keping biji setiap perlakuan. Untuk melihat secara visual, biji setengah fermentasi memperlihatkan warna ungu dominan terhadap coklat.

Menurut (Schwan, 1998) pembedaan warna ungu pada biji berlangsung secara bertahap dan berkolerasi dengan penurunan konsentrasi polifenol dan lamanya proses fermentasi. Oleh sebab itu, perubahan warna keping biji digunakan untuk penghentian proses fermentasi. Terjadinya perubahan warna pada biji kakao dikarenakan adanya kandungan antosicyanin yang dapat menyebabkan warna berubah dari ungu muda ke ungu gelap/ tua (Camu et aI.,2008).

\section{Biji Terfermentasi Sempurna}

Biji terfermentasi sempurna dilihat dengan adanya warna coklat gelap dari $80 \%$ pada kulit luar dan kotiledon serta adanya pori-pori kecil di dalam biji kakao. Untuk menentukan kualitas biji kakao kering yang dihasilkan, proses fermentasi menjadi komponen penting dalam hal ini karena proses fermentasi akan dapat merubah warna biji yang semula ungu dan pejal (massive) berangsur berubah menjadi coklat dan berongga.

Hasil dari analisis sidik ragam menunjukkan bahwa interaksi antar perlakuan tidak memberikan pengaruh nyata $(\mathrm{P}>0,05)$ terhadap hasil uji belah biji terfermentasi sempurna, selanjutnya perlakuan dimensi wadah fermentasi berpengaruh nyata $(\mathrm{P}<0,05)$ terhadap biji 
terfermentasi sempurna, sedangkan perlakuan lama fermentasi memberikan pengaruh sangat nyata $(\mathrm{P}<0,01)$ terhadap hasil uji belah biji terfermentasi sempurna. Nilai rata-rata hasil uji belah/cut test biji terfermentasi sempurna dan hasil Uji BNT dapat dilihat pada Tabel 7.

Tabel 7. Nilai rata-rata hasil uji belah biji terfermentasi sempurna (\%)

\begin{tabular}{|c|c|c|c|c|}
\hline \multirow{2}{*}{ Dimensi Wadah } & \multicolumn{3}{|c|}{ Lama Fermentasi } & \multirow{2}{*}{ Rata-rata } \\
\hline & B1 & B2 & B3 & \\
\hline A1 & $74 b$ & $74 a$ & $71 \mathrm{a}$ & 73 \\
\hline $\mathrm{A} 2$ & $76 \mathrm{~b}$ & $76 \mathrm{~b}$ & $71 \mathrm{a}$ & 74 \\
\hline A3 & $77 \mathrm{c}$ & $80 \mathrm{~d}$ & $71 \mathrm{a}$ & 76 \\
\hline Rata-rata & 76 & 77 & 71 & \\
\hline
\end{tabular}

Sama seperti halnya dengan parameter kadar air, jumlah biji per 100 gram dan kadar kulit, dimana perlakuan memberikan nilai terbaik pada parameter kadar air adalah perlakuan A3B2 begitu juga sama dengan perlakuan pada parameter jumlah biji per 100 gram dan kadar kulit. Berdasarkan data yang disajikan pada Tabel 7 , nilai rata-rata kadar biji terfermentasi sempurna yang paling tinggi terlihat pada perlakuan A3B2 yaitu dimensi wadah berukuran $23,5 \mathrm{~cm}$ x $23,5 \mathrm{~cm}$ x 29,5 dengan kapasitas 9,5 fermentasi selama 6 hari yaitu sebesar $80 \%$ yang memberikan pengaruh yang berbeda nyata dibandingkan dengan perlakuan lainnya. Perlakuan ini menjadi kondisi yang paling baik karena semakin tinggi persentase kadar biji terfermentasi sempurna maka semakin baik juga kualitas mutu biji kakao kering yang dihasilkan. Hal ini menunjukkan sudah sesuai dengan standar SNI 2323-2008 yaitu semakin rendah nilai persentase kadar biji tidak terfermentasi (slaty) maka kualitas mutu biji kakao kering hasil fermentasi akan semakin baik. Biji terfermentasi sempurna ditunjukkan dengan adanya warna coklat gelap pada $80 \%$, pada kulit luar dan kotiledon serta adanya pori-pori kecil di dalam biji kakao.

Berdasarkan penelitian yang dilakukan, menunjukkan bahwa biji kakao yang difermentasi secara penuh (fermented) dilihat dengan warna coklat tua pada biji, bentuk biji sebagian besar bulat, bila biji dibelah terdapat rongga-rongga didalamnya serta kulit biji tidak menempel pada keeping biji. Ciri-ciri ini terdapat pada perlakuan fermentasi selama 6 hari (B2), hal ini sesuai yang disebutkan oleh Siregar dkk (1989) bahwa biji kakao yang difermentasi secara penuh (fermented) dilihat dengan adanya warna coklat gelap pada $80 \%$ kulit luar biji kakao. Menurut Syarief dkk dalam Sumardi dkk (2001) menunjukkan bahwa proses fermentasi selesai jika pulp mudah dibersihkan dari kulit biji. Kulit biji kakao berwarna coklat dan berbau asam cuka.

\section{Biji Berjamur, Berkecambah, dan Berserangga}

Biji kakao yang berjamur tidak memiliki cita rasa coklat yang baik dan disertai cacat cita rasa musty, mouldy atau earthy (Yusianto dkk., 1995). Biji berjamur disebabkan oleh kapang yang menyerang permukaan biji lalu berpenetrasi ke dalam biji tersebut. Hal ini dikarenakan aktivitas air pada biji kakao mulai berkurang. Menurut Haryadi dan Supriyanto (2011), kapang yang tumbuh selama proses fermentasi sulit dihindari, karena kondisi di lingkungan sekitar yang terbuka dapat menjadi sumber kontaminan spora kapang. Berdasarkan hasil dari penelitian yang sudah dilakukan, tidak ada ditemukannya kadar biji berjamur, berkecambah dan berserangga pada semua perlakuan yang diberikan. Hal ini dikarenakan nilai kadar biji berjamur, berkecambah dan berserangga yaitu sebesar $0 \%$. Oleh sebab itu, perlakuan dimensi wadah dan lama fermentasi tidak memberikan pengaruh nyata terhadap kadar biji berjamur, berkecambah maupun berserangga. Hal ini disebabkan oleh pada saat proses fermentasi biji kakao, tingkat keberhasilan fermentasi berjalan dengan sempurna dan juga pada saat proses pengeringan tidak adanya sisa kadar air yang tinggi dari biji kakao sehingga biji kakao tidak mengalami kapang.

Dari semua parameter diatas, terlihat bahwa parameter suhu fermentasi dengan hasil uji belah biji terfermentasi sempurna menunjukkan hasil yang sama untuk mendapatkan perlakuan yang terbaik, dimana perlakuan terbaik yang mampu mencapai suhu fermentasi optimal sama dengan hasil uji belah biji terfermentasi sempurna yang 
mampu mengasilkan persentase biji paling banyak yaitu perlakuan A3B2. Begitu juga dengan parameter lain seperti kadar air, jumlah biji per 100 gram dan kadar kulit, menunjukkan perlakuan terbaik yaitu A3B2, karena nilai ratarata yang dihasilkan sudah memenuhi standar SNI 2323:2008 biji kakao kering hasil fermentasi.

\section{KESIMPULAN}

Berdasarkan penelitian yang sudah dilakukan , dapat disimpulkan bahwa suhu fermentasi biji kakao yang mampu mencapai suhu optimal yang terjadi setelah 48 jam fermentasi adalah perlakuan A3B2 yaitu dimensi kotak kayu berukuran 23,5 $\mathrm{cm}$ x 23,5 cm x 29,5 cm dengan kapasitas $9,5 \mathrm{~kg}$ yang difermentasikan selama 6 hari. Dari hal tersebut juga memperlihatkan hasil dari uji belah/cut test biji terfermentasi sempurna sebesar $80 \%$, menunjukkan perlakuan terbaik yang jumlah bijinya paling sedikit dari perlakuan lainnya. Selanjutnya terlihat juga pada parameter kadar air, jumlah biji per 100 gram dan kadar kulit, menunjukkan bahwa perlakuan terbaik adalah A3B2. Hal ini menunjukkan bahwa dimensi wadah kotak kayu paling besar (A3) sangat berpengaruh terhadapt kualitas biji kakao kering yang dihasilkan.

Suhu maksimal fermentasi yang dicapai sebesar $45,50{ }^{\circ} \mathrm{C}$, kadar air sebesar $74 \%$, jumlah biji per 100 gram sebesar 83, kadar kulit sebesar 10,97\%, hasil uji belah biji tidak terfermentasi $2 \%$, biji setengah fermentasi $18 \%$, biji terfermentasi sempurna $80 \%$ dan biji yang berjamur $0 \%$, berkecambah $0 \%$ dan berserangga $0 \%$. Dari hasil semua di atas yang menunjukkan perlakuan terbaik sudah memenuhi standar SNI 2323:2008.

\section{Saran}

Berdasarkan hasil penelitian yang telah dilaksanakan, adapun saran yang dapat diberikan adalah agar dilakukan proses fermentasi dengan menggunakan jenis kayu yang berbeda setiap perlakuan dan dilakukan dengan waktu fermentasi yang berbeda untuk mendapatkan mutu biji kakao kering terbaik.

\section{DAFTAR PUSTAKA}

Alam, N. A. N., Saleh, M. S., \& Hutomo, G. S. (2010). Karakteristik buah kakao yang dipanen pada berbagai ketinggian tempat tumbuh dan kelas kematangan. Agroland, 17(2).

Amin, A. S. (2005). Teknologi pasca panen kakao untuk masyarakat perkakaoan Indonesia.
BPPT Press, Badan Pengkajian dan Penerapan Teknologi.

Arief, R. W., \& Asnawi, R. (2011). Karakterisasi sifat fisik dan kimia beberapa jenis biji kakao lindak di Lampung. Journal of Industrial and Beverage Crops, 2(3), 325-330.

Aryani, N. A., Yulianti, N. L., \& Arda, G. Karakteristik Biji Kakao Hasil Fermentasi Kapasitas Kecil dengan Jenis Wadah dan Lama Fermentasi yang Berbeda. Jurnal BETA (Biosistem dan Teknik Pertanian), 6(1), 17-24.

Biji, P. F. K. S. F., \& Berperan, K. D. E. K. Y. Physico-Chemical Changes During Cocoa Fermentation and Key Enzymes Involed.

Camu, N., De Winter, T., Addo, S. K., Takrama, J. S., Bernaert, H., \& De Vuyst, L. (2008). Fermentation of cocoa beans: influence of microbial activities and polyphenol concentrations on the flavour of chocolate. Journal of the Science of Food and Agriculture, 88(13), 2288-2297.

Haryadi, M. S. (1991). Pengolahan Kakao Menjadi Bahan Pangan. Pusat Antar Universitas Pangan dan Gizi. Universitas Gajah Mada, Yogyakarta.

Hatmi, R. U., \& Rustijarno, S. (2012). Teknologi Pengolahan Biji Kakao Menuju SNI Biji Kakao 01-2323-2008. BPTP Yogyakarta.

Kustyawati, M. E., \& Setyani, S. (2012). Pengaruh penambahan inokulum campuran terhadap perubahan kimia dan mikrobiologi selama fermentasi coklat. Jurnal Teknologi \& Industri Hasil Pertanian, 13(2), 73-84.

Misnawi, S. J., Nazamid, S., \& Jamilah, B. (2002). Activation of remaining key enzymes in dried under-fermented cocoa beans and its effect on aroma precursor formation. Food Chemistry, 78(4), 407-417.

Nasional, B. S. (2008). Standar Nasional Indonesia (SNI) 01-2323-2008 (Biji Kakao, Bubuk Kakao dan Lemak Kakao).

Rasadi, Y. (2015). Karakteristik Fisik dan Kimia Biji Kakao (Theobroma cacao L.) Hasil Fermentasi Variasi Wadah Kotak Kayu, Krat Plastik dan Daun Pisang di Pusat Penelitian Kopi dan Kakao Indonesia. Skripsi SI. Fakultas Teknologi Pertanian Universitas Jember, Jember.

Rohan, T. A. (1963). Processing of Raw Cocoa from the Market. FAO Agriculture Studies, no. 60. Food and Agriculture Organization, Rome, Italy.

Poedjiwidodo, M. S. 1996. Sambung Samping Kakao. Jawa Tengah. Trubus Agriwidya. 
Sari, K. A. R. T. I. N. I. A. (2016). Pengaruh indeks kematangan buah kakao (Theobroma cacao L.) dan massa tumpukan terhadap kualitas hasil fermentasi biji kakao di Wilayah Gedong Tataan, Kabupaten Pesawaran, Lampung (Doctoral dissertation, Thesis, Universitas Lampung, Indonesia).

Schwan, R. F. (1998). Cocoa fermentations conducted with a defined microbial cocktail inoculum. Appl. Environ. Microbiol., 64(4), 1477-1483.

Sriwanda, N. (2018). Prospek Usaha Tani Kakao Kecamatan Bandar Baru Kabupaten Pidie Jaya. Jurnal Bisnis Tani, 3(2), 139-146.

Siregar, T. H., Riyadi, S., \& Nuraeni, L. (1989). Budidaya, pengolahan dan pemasaran cokelat. Penerbit Swadaya.

Wahyudi, T., Pangabean, T. R., \& Pujianto, P. (2008). Panduan Lengkap Kakao Manajemen Agribisnis dari Hulu hingga Hilir. Penebar Swadaya, Jakarta, 364.

Winarno, F. G. (1997). Kimia Pangan Dan Gizi. PT Gramedia Pustaka Utama Press, Jakarta, Indonesia.

Yusianto, H. W., \& Wahyudi, T. (1997). Mutu dan pola cita rasa biji beberapa klon kakao lindak. Pelita Perkebunan, 13, 171-187.

Yusianto. 1998. Analisis hubungan antar komponen cita rasa biji kakao. Pelita Perkebunan, 14 (2) : 124-140. 